DIGITAL COMMONS
@ UNIVERSITY OF SOUTH FLORIDA

Volume 7

Issue 2 Volume 7.2 (Fall 2017)

\section{ABO: Interactive Journal for Women in the Arts, 1640-1830}

\title{
Review of Laura Engel and Elaine McGirr, eds., Stage Mothers: Women, Work, and the Theater, 1660-1830
}

Kristina Straub

Carnegie Mellon University, ks3t@andrew.cmu.edu

Follow this and additional works at: https://digitalcommons.usf.edu/abo

Part of the Dramatic Literature, Criticism and Theory Commons, Educational Methods Commons, Feminist, Gender, and Sexuality Studies Commons, and the Literature in English, British Isles Commons

\section{Recommended Citation}

Straub, Kristina (2017) "Review of Laura Engel and Elaine McGirr, eds., Stage Mothers: Women, Work, and the Theater, 1660-1830," ABO: Interactive Journal for Women in the Arts, 1640-1830: Vol.7: Iss.2, Article 8. http://doi.org/10.5038/2157-7129.7.2.1160

Available at: https://digitalcommons.usf.edu/abo/vol7/iss2/8

This Reviews is brought to you for free and open access by Digital Commons @ University of South Florida. It has been accepted for inclusion in ABO: Interactive Journal for Women in the Arts, 1640-1830 by an authorized administrator of Digital Commons @ University of South Florida. For more information, please contact digitalcommons@usf.edu. 
Review of Laura Engel and Elaine McGirr, eds., Stage Mothers: Women, Work, and the Theater, $1660-1830$

\author{
Abstract \\ Stage Mothers is a collection of essays that complicate the binary between female professional and \\ domestic mother, contributing to theater history and the history of female professionalization and \\ maternity. \\ Keywords \\ Maternity, Theater, Actress \\ Creative Commons License \\ (c) $($ ) $\ominus$
}

This work is licensed under a Creative Commons Attribution-No Derivative Works 3.0 License. 
Engel, Laura, and Elaine McGirr, editors. Stage Mothers: Women, Work, and the Theater, 1660-1830. Bucknell UP. 2014. xv + 274pp. Index. ISBN: 978-1-6114-8605-6.

Reviewed by Kristina Straub

Carnegie Mellon University

Stage Mothers brings together a collection of essays that seek to complicate, as Elaine McGirr and Laura Engel explain in their introduction, the binary between maternal femininity as a normative ideal and the sexualized image of the whore that dominates perceptions of the eighteenth-century actress. Informed by the fields of feminist theory, theater history, and performance studies, this collection builds on much excellent work on women's writing in the period (Marilyn Francus's Monstrous Motherhood playing a key role) to consider both aesthetic and everyday performances of real and fictional women who were mothers - and more than mothers.

The book is divided into three sections, one focused on the careers of women who were both actresses and mothers, a second on stage representations of mothers, and a third on the relationships between actresses and their children on and off the British stage over the course of the long Eighteenth century. More than a history of female theatrical professionals as mothers, this collection shows us the actress's importance to fleshing out the history of maternity with the evidence of women's experience, as well as dominant ideologies of domesticity. While working mothers have a long history among laboring women, the history of the acting profession in the eighteenth century reveals the advent of the female professional who must also inhabit the supposedly domestic role of mother. This book is, then, not just about actresses (though it is gloriously so that); it is also about the history of female professionals, many of whom are mothers. In a real sense, it speaks to the history of this book's present readership, and it is no coincidence that both editors, as well as many of the contributors, are working professionals and moms.

The first four chapters focus on careers, how actresses combine professionalism with maternity. Helen Brooks juxtaposes the idealized mother at the core of domestic ideology with the lived experience of the actress/mother to create a complex picture both of what it meant to be a mother and what it meant to be an actress. As she argues, maternity was key to the formation of the actress's social role and identity; at the same time, her essay gives strong evidence of how critical the actress's lived experience as mother was to what maternity could mean. That actresses stitched together the ostensibly contradictory roles of public performance and maternal duty was a publically accepted fact in perceptions of the theater. The eighteenth-century actress made people think in terms that did not separate the domestic from the public, the maternal from the professional. However inadequate the economic and social support for professional moms (then and now), it cannot be said that this dual role was not widely understood and accepted.

J. D. Phillipson explores Anne Oldfield's balancing act between her "real" and "represented" identities. Drawing on Joseph Roach's theories of celebrity, Phillipson shows us how Oldfield's offstage performance as the lover, successively, of two publically respected men and the mother of their children informed her choices of roles 
and how she performed them on the stage - and vice versa. In this dialectic between biographical "reality" and fictional character, Oldfield's pregnant body could signify her offstage status in relation to her lovers as well as her identity as sexualized actress. Elaine McGirr's chapter on Susannah Maria Cibber ties the actress's "rehabilitation" after a scandalous adultery trial to her performance as the bereaved mother, Constance, in the revival of King John staged by Garrick in competition with Colley Cibber's production of that play. McGirr argues that public knowledge of Susannah Maria's image as a woman "more sinned against than sinning" in the context of her adultery trial and her subsequent domestic life, including children, with William Sloper, made her performance of maternal grief "real" and therefore superior to the "represented" grief of Hannah Pritchard, her rival.

The much-discussed public image-making strategies of Sarah Siddons are compared to Mary Robinson's parallel efforts in Ellen Malenas Ledoux's chapter on "Working Mothers on the Romantic Stage." Ledoux pushes back against the tendency to map these two actresses onto the binary of maternal virtue (Siddons) versus whorish sexuality (Robinson). Both women shaped their public reputations in response to the often-conflicting demands of the maternal body and making a living on the stage. Robinson's physical illness necessitated different strategies of self-representation than Siddons' healthy but widening girth - the former depended on text more than embodied performance - but both women defined their public images in relation to their identities as mothers.

With Laura J. Rosenthal's "Rebels for Love," the book turns to how mothers are represented on the stage. Rosenthal situates Mustapha, the1665 hit play by Roger Boyle, Earl of Orrery, in the context of Restoration politics and English knowledge of the Ottoman Empire. Records of affective responses to the spectacle of flawed, but sympathetic maternal feeling as embodied in Elizabeth Barry's pathetic performance support Rosenthal's argument for maternal feeling as a cosmopolitan impulse that transcends nationality. Most significantly, Barry's performance made room for the public circulation of ambivalence about the personal and social costs of absolutist monarchy. The stepmother in Nicholas Rowe's Ambitious Stepmother, according to Marilyn Francus, also brings onto the stage questions about political authority. Francus shows us how Rowe, following John Locke, decouples political and familial structures of power. While resolutely masculinist, the play questions the validity of political power based on the patriarchal family. The mother, in this play, is instrumental in clearing the way for a Whig vision of monarchical succession that is not based on blood and family, but open to meritocracy.

Kathryn Lowerre combines the themes of representation on the stage and female performers' careers in a look at how two Italian operas, popular in London of the 1720s, represented mothers. Cornelia in Handel's Giulio Cesare and Griselda, in Bononcini's opera of that name, model feminine strength and virtue on the stage; the English soprano Anastasia Robinson, who played both roles, brought that model into her life as a long-suffering Catholic wife and mother who secretly married into the British aristocracy. A complex chapter by Emry Jones on Frances Sheridan's maternal legacy in the plays of 
her son, Richard Brinsley Sheridan, draws on Francus's powerful theorization of the spectral mother in Monstrous Motherhood: Eighteenth-Century Culture and the Ideology of Domesticity: the powerful presence, in texts and performance, of the absent mother who, watching or just remembered, exerts her influence all the more powerfully for not being there. Jones traces not only the textual legacy of the mother but potential "ghosts" of the mother that haunt subsequent performances, particularly of the son's plays. This chapter ends with a reading of Mrs. Malaprop as heir to Frances' Mrs. Tryfort, concluding with "the impossibility of ever policing the channels of inheritance with absolute authority, of ever silencing or even firmly pinpointing the influence of the spectral mother" (175).

Jade Higa gives us a fascinating reading of responses to Horace Walpole's The Mysterious Mother as they reverberate through subsequent responses to Lady Diana Beauclerk's illustrations of that play about maternal sexuality and incest, as well as responses to the physical space at Strawberry Hill in which Walpole housed both play and illustrations. Using Eve Sedgwick's notion of "gothic contagion," she traces the restoration of audience response as performance, to use performance theorist Richard Schechner's concept. An implicitly and explicitly deviant maternal sexuality is restored through text, images, space, and, finally, the family of Diana Beauclerk herself, whose children engaged in an incestuous affair. Maternity, in Walpole's play and in Higa's reading of its reception, takes a decidedly queer turn.

Judith Hawley begins a section on mothers and children with a well-researched and richly speculative essay on Elizabeth Craven and her son Keppel, co-stars in thirty years' worth of private theatricals. Hawley usefully points out the problematic nature of "private" in private theatricals, which were often as fully publicized as commercial theatre. In Hawley's words, "aristocratic women were always already celebrities" (202), and private theatricals gave artistic form to this public display. The relationship between Craven mother and son played out on the stage in inappropriate couplings - as brothers, for example, with the mother playing the trouser role. Hawley sees Elizabeth Craven as acting out of a narcissism that did not allow her to distinguish between herself and her son, an observation that queers the family, although Hawley does not use that verb. Like Lover's Vows in Mansfield Park, which Hawley mentions, private theatricals in this household are catalysts for transgression against sexual and social norms.

Laura Engels provides an evocative chapter on the complex relationship between Sarah Siddons, her daughters Sally and Maria, and the portrait painter Thomas Lawrence. Despite the destructive effects of Lawrence's romantic entanglements with both daughters, Siddons maintained a long and close relationship with the painter that Engels reads as falling outside the definitions of intimacy allowed by a heteronormative framework of family and love. Her relationship with her daughters is equally resistant to dominant narratives of domestic femininity. As a working mother who was absent from her children for long periods of time, Siddons functioned as a "spectral mother" (again, Marilyn Francus's influential phrase). Engels points out the overlap between the "public intimacy," to use Joseph Roach's term, with which fans relate to celebrities and the ways in which children relate to a physically absent but emotionally present mother, especially 
through objects such as hair and jewelry that "stand in" for the spectral mother. Francus's "spectral mother" has, indeed, a haunting presence in this collection, and comes into play again in Gilli Bush-Bailey's chapter on the early nineteenth-century actress Fanny Kelly. Bush-Bailey juxtaposes reviews of Kelly's melodramatic performance of a "secret" mother on the stage in 1829 with the "mystery" of the actress's "adoption" of a baby girl just before the opening of this well-received performance of maternal pathos. Sister Ursula, the character Kelly played so effectively, is mother to a child whom she cannot acknowledge as her own without disgrace. Hence, her presence is "spectral," the watching presence of an absent mother. Kelly's biography parallels this performance of spectral motherhood in real life, as Bush-Bailey's meticulous archival research unfolds the story of a secret pregnancy, birth, and the child's subsequent "adoption." Maternity, however, is not confined, in this history, to the domestic family, but is part of a "theatrical matriarchy" (247) in which Kelly plays the role of spectral mother not just to her daughter, but the women students she mentored and taught to perform.

Maternity, by the time this book is done with it, far exceeds in interest and complexity the static image of the mother whose energies focus exclusively on raising children and the home. Stage Mothers, in this collection, could also be called Queer Mothers in that they often defy the norms of the heteronormative family. While the actress may, as this book documents, be an historical exception to domestically defined maternity, her relevance to women who both parent and sustain a professional career is dramatically clear. Besides speaking to our interests in eighteenth-century women's writing and performance, this volume develops the history that leads to the current conditions in which many of us work and mother. Stage Mothers demonstrates the importance of the theater to the history of women's professions, as well as giving us an enriched and nuanced picture of eighteenth-century actresses' lives and work. 